\title{
WOMEN AND PUBLIC RELATIONS: A STUDY ON TURKEY'S FEMALE PR EXPERTS
}

\author{
Tuğçe ERTEM ERAY*, PInar ASLAN**
}

Received: 20.06.2019 - Accepted: 10.09.2019

Ertem Eray, T. ve Aslan, P. (2019). “Women and Public Relations: A Study on Turkey's Female PR Experts". Etkileşim. 4. 152-166.

\begin{abstract}
As of 1980s, Turkey has been more active in the field of public relations thanks to the accelerating effects of globalization and formalization of public relations education. Female domination has long been the situation in the sector and this leads to the perception that public relations is a woman's job. Since the literature review shows that there are few studies conducted in Turkey regarding the situation and the importance of women in the field of public relations is not emphasized enough, this study intends to make a current evaluation on the role and the place of Turkish women in the field of public relations. Therefore, female public relations experts and academics have been interviewed with the aim of detecting the place and importance of women in the field of public relations in Turkey. The data collected shows that the reason why there are more women than men in this field is the sexist point of view. Problems in the academic education and job definition of the profession result in the misperception of public relations in Turkey. It is seen that public relations which is associated with womanly behavior is not preferred by men as a profession. Furthermore, the fact that women work more as technicians whereas men work as executives in the sector and salaries are two issues that have come up throughout the study.
\end{abstract}

Keywords: public relations, women, public relations practitioners, public relations academicians.

\footnotetext{
* PhD, University of Oregon, School of Journalism and Communication, tugcee@uoregon.edu, Orcid: 0000-0002-5199-3159

**Lecturer/PhD, Üsküdar University, Faculty of Communication, pinar.aslan@uskudar.edu.tr, Orcid: 0000-0002-2500-8055
} 


\title{
KADIN VE HALKLA ILIŞKILER: TÜRKIYE'DE KADIN HALKLA ILIŞKILER UZMANLARI ÜZERINE BIR ÇALIŞMA
}

\author{
Tuğçe ERTEM ERAY*, PInar ASLAN**
}

\author{
Gönderim Tarihi:20.06.2019 - Kabul Tarihi: 10.09.2019 \\ Ertem Eray, T. ve Aslan, P. (2019). “Women and Public Relations: A Study \\ on Turkey's Female PR Experts". Etkileşim. 4. 152-166.
}

\begin{abstract}
Özet
Türkiye'nin halkla ilişkiler faaliyetleri gerçekleştirilen bir ülke haline gelmesi küreselleşmenin artan etkileri ve halkla ilişkiler eğitimindeki biçimlendirmeyle sayesinde 1980'li yıllarda olmuştur. Halkla ilişkiler sektöründe uzun zamandır kadın egemenliği söz konusudur ve bu da bu mesleğin kadın mesleği olarak algılanmasına neden olmaktadır. Literatür taraması Türkiye'de bu duruma dair yeterli çalışma olmadığını ve halkla ilişkiler sektöründe kadının öneminin yeterince vurgulanmadığını gösterdiğinden, bu çalışma Türk kadınının halkla ilişkiler sektöründeki yeri ve önemine dair bir değerlendirme yapmayı amaçlamaktadır. Çalışma kapsamında halkla ilişkiler alanından uzman veya akademisyen kadınlarla Türkiye'de halkla ilişkiler sektöründe kadının yeri ve önemi konulu görüşmeler gerçekleştirilmiştir. Toplanan verinin analizi halkla ilişkiler sektöründe kadınların sayıca erkeklerden fazla olmasının sebebinin cinsiyetçi bakış açısı olduğunu göstermektedir. Akademik eğitimde ve iş tanımındaki sorunların da Türkiye'de halkla ilişkilere dair yanlış bir algı oluşmasına sebep olduğu görülmektedir. Kadınlarla ve kadın doğasına yakıştırılan davranışlarla bağdaştırılan halkla ilişkilerin erkekler tarafından tercih edilmediği de çalışmada varılan sonuçlardan biridir. Ayrıca kadınların sektörde çoğunluk olmasına rağmen yönetici pozisyonlarında azınlık olması ve maaş sorunları da araştırmada öne çıkan konulardır.
\end{abstract}

Anahtar Kelimeler: halkla ilişkiler, kadın, halkla ilişkiler uygulayıcıları, halkla ilişkiler akademisyenleri. 


\section{Introduction}

Globalization has brought about the rapid spread of public relations throughout the world and Turkey has received its share. While in 1970s mostly foreign companies had public relations departments in Turkey, at the end of 1980s and especially during 1990s, most private Turkish companies started to have public relations departments as well (Okay and Okay, 2007). The number of communication faculties and with that, an academic tendency towards public relations researches and practices as a scholarship increased in the same period (Erdoğan, 2008). Although the development of public relations started late in Turkey, public relations experts and academicians are striving to reach the globally contemporary professional level.

The development of public relations in Turkey is realized with the common effort of male and female public relations experts, and more women take place in the field of public relations than men today (Öksüz and Görpe, 2014). One of these women, Betûl Mardin has had a major role in the development of public relations in 1970s, undertook the chairpersonship of Turkish Public Relations Association. She played an active role in International Public Relations Association (IPRA) for years and before she was elected as the President in 1995, she worked as an accountant in IPRA Board of Management. Therefore, it is seen that women cannot be ignored in the development of public relations in Turkey.

Public relations is an occupation that is frequently preferred by women all over the world. There have been many studies about the domination of women in the field of public relations e.g. (Cline et al, 1998; Grunig, Hon, Toth, 2001; Toth and Cline, 1989; Toth et al, 1998; Wright et al, 1991). These studies have different perspectives on women in public relations, hence, they have different results besides the fact that they all draw attention to the majority of women compared to men. Since public relations is considered as a "woman's job" it is also present in the list of "best jobs for women" (Nasr, 2015). In addition, female students dominate public relations students which also shows that women will remain a majority in this field in the future. The situation is no different in Turkey. For example, Yıldırım and Metin (2006) stated that public relations is perceived as a woman's job after their study on university students. However, it is notable that studies on women in public relations field in Turkey are quite few. This study derives from the matter that there are not many studies on the importance of women in public relations in Turkish literature compared to the international studies which focus mainly on women in this field. The aim is to fill the gap in existing knowledge by explaining the role of Turkish women in public relations from a historical perspective. 


\section{Literature Review}

\section{Women in public relations field}

The ratio of women sharing the labor force in public relations has been gradually rising since the 1970 s. At the beginning of 1960 's, women constituted $25 \%$ of the public relations expert category according to the US Bureau of Labor Statistics. The ratio of women to men was equal in 1982. Today, this field is $2 / 3$ women, and it is still seen as a part of the pink industry (Khazan, 2014; PR Daily, 2016; Salzman, 2014). Overall, it is possible to say that domination of women in this field has long been present.

The main reasons women have a gradually increasing domination over men in the field of public relations are the failure in drawing men's attention to this industry after 1970's and filling the gaps in the industry with women. From 1970 to 1980 , the decline in the salaries in public relations field made male experts prefer management positions with higher salaries and this resulted in female experts to work in junior and technical positions. This doubtlessly turns women into cheap labor force. On the other hand, flexible working hours and less sexist barries (compared to other jobs) are the reasons that draw women to public relations industry. Positive discrimination causes women to be preferred over men in employment and ideology of gender claims that public relations is an emotional job and it is more appropriate for women. Another reason is the fact that women are better in jobs that require social skills. Furthermore, the opportunities that the field of public relations present are also a source of attraction for women (Becerikli, 2008). All these cause the situation that there are more women than men in public relations and this is the reason why this profession is perceived as a "woman's job".

RQ1: "What factors affected opportunities for women's advancement in public relations in Turkey?"

Despite the woman domination in this field, it is possible to say that women face many problems. Two of the biggest problems women encounter in the field of public relations are the issues of salary and status inequality (Hon et $\mathrm{al}, 2005)$. One of the most important academic studies on these problems is Broom's (1982) research on organizational roles which shows that there are more men than women in management positions and women work mostly as technicians. In another study, Broom and Dozier (1986) found out that there are notable differences between men's and women's salaries. After these main studies, many other studies themed gender, roles and salaries in public relations have been conducted. For example, Aldoory and Toth (2002) emphasized that gender discrepancies in hiring, salary, and promotions have been found in quantitative and qualitative researches in public relations and these researches indicate that although the public relations profession is almost $70 \%$ women today, men are often favored for hiring, higher salaries, and promotions to management positions. 
In addition, these abovementioned issues can be found in different countries around the world. For example, Al Saqer (2008: 78) found that women faced several kinds of challenges in their work in Bahrain such as cultural challenges, corporate environment, relationship with their colleagues, personal life, and social domination. Erzikova and Berger (2016) addressed that women practitioners in Russia are either hesitant or unable to take the leadership role due to the existing societal and professional gender stereotypes, male-dominated organizational culture, and lack of support from professional associations. These studies draw attention to the domination of women, and they also focus on the problems women encounter; hence, it is worth attention that women may encounter problems even in an area where they are the majority.

RQ2: "What are the challenges and barriers they have faced as women working in public relations in Turkey?"

\section{Women and public relations in Turkey}

According to the recent data by Turkish Statistical Institute (TÜiK, 2018), women constitute $49,8 \%$ of Turkish society and the ratio of women who are illiterate are five times higher than illiterate men. In the population that is 15+, the rate of employment is $65,1 \%$ in men whereas it is solely $28 \%$ in women. As we can see, the rate of women who are employed in Turkey is low. When the field of public relations is examined, it can be seen that women are a majority despite the low rates of women employment in the country.

There are some certain milestones in the development of public relations as a profession in Turkey. Among these are State Planning Organisation studies, the MEHTAP report, the foundation of the first public relations department, publications of the first PR books, the establishment of the Turkish Public Relations Association, the establishment of the first PR department at Koç Holding and the foundation of first PR agency. In this process, two people are actively involved: Father and mother of Turkish PR, Alaeddin Asna and Betûl Mardin (Bıçakçı and Hürmeriç, 2013). Hence, the development of public relations in Turkey is thanks to the cooperation of women and men. However, in the later period, public relations started to become a rather woman's job. For instance, Betûl Mardin started to work as a freelance PR consultant for the first time in Istanbul in 1969. Turkish Public Relations Association (TÜHID, 2018a) currently has a woman as the chairman. Apart from the chairman, Gonca Karakaş, the board of directors also have many women such as Fügen Toksu, Sevil Wittmann, Berna Sağlam Naipoğlu, Sıla Gök and Şulecan Dalbudak Toközlü. According to the list of members on the website, $76 \%$ of the members (that are 153 people) are women (TÜHID, 2018b). In addition, the number of women academicians are much higher than the number of men in Turkish communication faculties (TÜHID, 2018C).

Women are also worth attention when it comes to the internationalization of Turkish public relations. Turkish public relations was first represented in the 
international arena by Global Tanıtım and the company became an affiliate of Fleishman-Hillard. This was the first step of internationalization according to some experts (Bıçakçı and Hürmeriç, 2013). Later, in 1992, Betûl Mardin became a member of International Public Relations Association (IPRA) Board of Directors, and the first Turkish President of IPRA in 1995. Mardin is a member of European Public Relations Federation and the Public Relations Foundation besides being the second President of the Turkish Public Relations Association. Furthermore, in 1998, she received a Member Emeritus degree from IPRA. Besides Betûl Mardin, Ceyda Aydede and Zehra Güngör are the other Turkish women public relations experts that served as president for IPRA. However, there is not much information about how other women developed their careers in the 1980s and 1990s.

$R Q 3:$ "How did women develop their careers in public relations in the 1980s and 1990s?"

There are a few studies that focus on women in public relations field in Turkey. For example, Ciner (2003) found out that women face discriminatory attitude and behavior in many phases starting from employment and going on in work life and their level of perceiving this discrimination is low nonetheless. In a study conducted by Öksüz and Görpe (2014), interviewees considered the issue from a nonsexist angle and stated that public relations is not a job that is peculiar to women. Another study is conducted by Tanyıldızı (2011) indicated that women public relations practitioners are mostly satisfied with their jobs in Turkey. However, these practitioners also explained that they are not happy with the current situation of public relations since it is seen as a woman's job. The fact that all these studies differ in results indicates the need to have more studies on today's female public relations experts. key?"

RQ4: "What is the current situation for women in public relations in Tur-

\section{Method}

In this study, which is conducted with the idea that there should be more research on women in the field of public relations, the aim is to find out the roles and place of women in public relations in Turkey from a historical perspective. Within the scope of the study, qualitative interviews are conducted. This method is convenient within the scope of the study because it gives the researcher an opportunity to understand how social and cultural contexts play significant roles in interviewees' thoughts and actions. Thus, the researcher finds out the roles and the place of the women in public relations field by considering the history of social and cultural context in Turkey.

This study is conducted in Istanbul because the city has a large public relations community in general. Most of the public relations agencies and communication faculties are in Istanbul. McCracken (1951) suggests the "less is more" 
principle while selecting the respondents since it is crucial to have research on the topic through few people while paying longer and greater attention. Thus, this study included a total of 12 women in public relations field.

Lindlof and Taylor (2017) state that researchers select people for interviews if their experience is central to the subject that they study. The main objective of qualitative interviews is to understand a person's experience, worldview, or ideological affiliation; therefore, this can only be possible to interview with someone who has 'been there' or 'is there'. Since this study aims to understand women's experience and worldview in public relations, 5 female public relations practitioners who work either in an agency or in a governmental or non-governmental organization and 7 female academicians from either state or private universities were interviewed. All of the interviews were recorded with the consent of the participants. The duration of the interviews varies between 90 minutes and 2.5 hours. Eight of the interviews took place at the participant's workplace while four of them took place at a coffee shop that participants preferred.

This study used a purposive sample of female public relations practitioners and scholars who work either in an agency or in a governmental or non-governmental organization and either state or private universities in Turkey to answer the research questions. Some interviewees are selected by the author to serve the purpose of the study, while others are chosen using snowballing method. This strategy was very helpful to find out participants who have specific knowledge, skills and characteristics because similar to advertising community (Chavez, 2012, p. 6), public relations community also know each other, have worked and competed with one another and largely attend the same conferences, conventions and social events. The main criterion of the sampling was that all the selected participants need to be Turkish females who are coming from different areas of public relations.

\section{Findings}

Participants were asked questions that were related to the research questions of the study. For $R Q 1$, that is factors affected opportunities for women's advancement in public relations in Turkey, interviewees were asked two questions. The first question is about the reasons why there are more female public relations practitioners than male ones in Turkey. One of the interviewees stated that the reason was because the profession started to develop before the formation of educational groundwork:

(...) public relations was mistaken for services such as welcoming, accompanying, hospitality, entertaining people which are rather feminine. That is why women were preferred over men, they believed that elegance of women was an added value of this profession. (agency employee-P2)

Besides the educational formation, another issue that was rather more 
frequently mentioned was the sexist perspective. According to many interviewees, this is the main reason why there are more females than males in the public relations sector:

I believe this is seen as a woman's profession due to the sexist perspective. (academician-P1)

The social perspective which believes that engineering, finance, and law are manly professions which can employ men similarly indicates that there may be some jobs also for women. Professions such as nursery, assistance, teaching are accepted as professions for women. In this context, according to the social perspective, public relations is a profession for women. (academician-P6)

It is remarkable that this is the shared opinion of both public relations professionals and public relations academicians:

Public relations is perceived as a profession suitable rather for women. (agency employee-P11)

I believe the main reason is the employment policies of employers. Second reason may be an old habit that stems from the past of Turkey... the mission and role of this profession is compatible with women's skills in relationships and management that comes from their biological potential. (government professional-P12)

Another question directed at the interviewees is "What are the factors that made women move forward in the field of public relations?" regarding the $R Q 1$. Answers participants give to that question include the sexist approach, an issue that was referred to for the first question as well, and the features that are believed to be matching women:

The fact that women's way of thinking is different than men and women are more into details" (academician-P1).

Being smooth-faced and smooth-spoken, having a natural tendency to be hospitable, having the skills for problem solving and multitasking, being patient, calm, compromising, careful with details and elegant... (agency employee-P2)

The fact that women are meticulous, careful and hardworking. (academician-P5)

Public relations has some principles like which has mutuality, trust, tolerance, indulgence and these principles are seen rather more connected to woman's social roles, behavior and personality traits. Since the application of public relations and management of communication processes require carefulness and attention, public relations is perceived as a job for women and women are perceived as practitioners that could contribute more to reaching the targets of public relations. (academician-P6)

Although it is rather commonly accepted that females have the crucial features that make them "better public relations experts", these features are not very visible in other sectors. Some interviewees even think that females have more advantages than men in the employment process if it is a public relations job. There is a demand for women in this sector.

There may be many factors like choosing women over men in employment pro- 
cess due to the perception that it is a woman's job, or thinking that women are more patient, compromising, open to communication, meticulous, and successful at organizing. (agency employee-P7)

The increasing demand of women regarding this profession, the thought that this is a profession that is appropriate for women's labour force, the skills women have on cooperation and relationship management, the perception some countries have as public relations is a female profession, the fact that women are more skilled in understanding the customers since they are more kind hearted... (government professional-P9)

When participants are asked the question "What do you think are the challenges women face in the field of public relations?" for the second research question of the study, they emphasize the low salaries which is in line with their previous answers. The matter of salaries also includes the fact that female public relations practitioners get paid less than males since women are the majority in lower positions. According to the interviewees, the fact that men dominate the higher positions in public relations sector also leads to the problem of male harassment.

The facts like getting paid less than a man even when they are in the same company doing the same job, having less chances of promotion, seeing the unwillingness of a male director in working at the same position as a woman are the reasons why women cannot move forward. Furthermore, women may give in thinking that they will not be promoted anyway, and they may also feel the obligation to put up with mobbing. (academician-P5)

As long as this profession is considered as a woman's job, these negative situations will arise. One of this is the issue of salary. In many parts of the world, women earn less than men. It is another challenge that women will not bear the workload since they are rather weak and fragile. There may also be the issue of harassment by men. (agency employee-P7)

There may be many challenges such as the low employment rate of women in managerial positions in patriarchal societies, the perception that public relations is a woman's job, the fact that this profession has a general problem of misunderstanding due to marketing and business administration crossroads, extremely flexible hours of working, the possibility of experiencing male harassment, and the fact that women are more emotional. (governmental professional-P9)

Another challenge for women public relations experts is due to the gender definitions. The reason the interviewees believe that the perception women are better at implementing rather than creating public relations practices is one of the biggest challenges females encounter in today's public relations sector:

In today's world where communication practices are planned through corporate strategies, the perception that women are better in implementing rather than creating is the biggest challenge women face. On the other hand, a great proportion of the companies in this sector are founded or directed by women. In our country where many professions are dominated by men it is, of course, possible to witness that men are rather reluctant in consulting a woman or agreeing to be 
oriented by one. (agency employee-P2)

One of the interviewees gave a very short description of the challenges with a concluding remark that is worth attention: today's public relations profession simply does not satisfy women although they are the majority and greater force in the sector.

The salary which cannot meet the effort produced and the inconsistency in society's perspective are surely serious problems. This profession does not satisfy women. (academician-P3)

For the third research question of this study, participants are asked about the development of woman in the field of public relations as of 1980s since it is the time when public relations started to develop as a profession in Turkey. Participants mostly emphasized the development of a rather professional definition of public relations and the improvement of the quality of education. One of the most commonly indicated issues is the fact that public relations was a field that was practiced by people who were not professionals at first and this caused a certain chaotic definition of the job:

Women had always been represented in public relations. However, there were problems in definition of the profession and women represented were symbolized with other women from other professions. Regarding this, we can say that there is a positive change. (academician-P1)

First practitioners of this field were not women who were professionally developed. They were models. As of $1980 \mathrm{~s}$, evaluation of the incidents with a rather more holistic approach and consideration of communication studies with a different point of view have brought a new perspective to public relations. We can now see that women do not see public relations from a gender perspective. We also see that today there are more professional education. Along with these educations, perspective also changes because men and women get these educations together. So, men also change their gender perspective. They are more developed on this when it comes to salary or other issues compared to past. (academician-P3)

All these changes led to the current situation of the field of public relations where the field and job definitions have become clearer. According to some participants, this change is also related to a wider framework that is shaped by globalization. When the companies increase in number, practices by public relations become an important benefit to create a difference.

The meaning and the field of public relations has become clearer in time; many agencies have been founded and all the organizations have had public relations or similar departments. With such a development, in this field which serves in creating information and messages and transmitting images to publics through print or online channels there have been women who studied, worked, and developed their careers. (agency employee - P4)

There has been a great acceleration in the field of public relations, especially in the last 10 years. As globalization has speeded up, multinational companies have increased in number and competition has become global since 1980 s, public re- 
lations practice has become impossible to ignore. In this period, number of communication faculties also increased, and the quality of education has improved. It has been realized that practice is to be considered seriously besides theory and the importance of internships is agreed upon. Graduate studies on this field or on interdisciplinary matters made the graduates more qualified. This is the time when women practitioners in the field of public relations made it to higher positions. (academician - P8)

Education is very much related to the current situation of public relations. Thanks to the multidisciplinary feature of public relations education, women have had the vision to improve themselves and become better at social skills.

As women had more place in work life, as they had more education and as this sector is open to personal and professional development, women have become more interested in public relations and their level of success has increased. (agency employee-P11)

When asked to make an overall evaluation on women in public relations in today's world, most of the participants draw attention to the fact that the field of public relations in Turkey has been developing and this development surely changed the perception of the profession. They underline the fact that the place of women does also improve with the change in the perception of the profession:

Today woman carry out many successful campaigns in public relations. In addition to serving important brands and institutions as consultants, they also create aspiring projects and contribute to the country's physical and social sustainability. (agency employee-P4)

I believe that there has been an increase in the rate of women who work in the positions like public relations department manager or public relations agency director, they no longer work as technicians at all. (academician-P5)

Although there is a considerable improvement in public relations sector in many aspects, contradictory situation of the job definition for women remains. Women are the majority, yet they earn and manage less.

Today, the point of view regarding women in the field of public relations has reflections like the high rate of employment of women; but, the obstacles women encounter in getting managerial positions form a contradictory situation. It is necessary for women to gain their place in managerial positions beside their majority in the sector. It will be a basic indicator of the situation that women have gained the value and status they deserve when they will have more positions like managers or directors besides practitioners. (academician-P6)

While making an overall evaluation of the public relations sector in Turkey, participants frequently mention the importance of education. Educational formation helps female public relations practitioners to become better professionals and to do their jobs more successfully.

(...) It is important that practitioners of this profession are educated, and they have the necessary requisites to work in this field. In this perspective, it is pos- 
sible to say that there are more women than men in the field of public relations either in the sector or the academic world. Yes, they face many challenges, but they do their job successfully. (agency employee-P7)

(...) The profession of public relations is getting away from job definitions such as organizing events and serving as a sales assistant or secretary, the definitions of the times 15-20 years ago. Today, public relations experts working in big or multinational companies serve as consultants to the management, manage the communication of the company with its internal and external stakeholders, play an active role in strategic decision making regarding companies' future. As women's level of education increases, so do the chances of women's more actively engagement in work life. The increase in Turkish women's level of education surely reflects on the field of public relations. (academician-P8)

\section{Conclusion}

Female domination in the field of public relations which is perceived as a woman's job is the common finding of many studies and research papers. There are few studies conducted in Turkey regarding the matter and the importance of women in the field of public relations is not emphasized enough. Therefore, this study aimed to fill this gap by explaining the role and the place of Turkish women in the field of public relations.

In this study, 12 women from the field have been interviewed with the aim of detecting the place and importance of women in the field of public relations in Turkey. The rate of women who work as either practitioners or academicians is quite high in this field globally and this situation is also existent in Turkey. The data collected shows that the reason why there are more women than men in this field is the sexist point of view. Turkey, as well as all the world, sees public relations as a woman's job. Problems in the academic education and job definition of the profession result in the misperception of public relations in Turkey. It is seen that public relations which is associated with womanly behavior is not preferred by men as a profession. Likewise, the data collected from the interviews indicates that the biggest obstacle women encounter in their professional development is the sexist perspective. This idea is in line with the reasons that have been found out in the literature about having more women in the sector. Ideology of gender considers public relations as an emotional job which is more suitable for women and this is also applicable in Turkey. The fact that women are more skilled in social relations make women have a higher rate in this field. However, contribution of women to the development of the field in Turkey is not to be ignored since women are at the forefront of the professionalization and internationalization of public relations in Turkey.

In 1970s, big and especially foreign institutions in Turkey had public relations departments whereas many governmental or non-governmental started to have public relations departments as of 1980s. The need for qualified 
personnel as a result of globalization caused an increase in the number of educational institutions giving quality education and this resulted in the embracement of public relations research and practices as of 1990s. Participants in this study mostly stated that developments in the job definitions of public relations have been experienced as of 1980 s along with the increasing quality in education. This doubtlessly affected the development of women in the field because the meaning of the field and the function of the profession have improved and this improvement is going on. The change in the perception of society regarding this profession has surely affected the perception of women working in this field. With the quality education and professionalization of public relations, there came along the rise of women to rather more managerial positions. With such developments, women working as public relations practitioners have stated that they are more satisfied with their jobs compared to past.

As the interviews also raised questions about the problems women encounter in the field of public relations, it is possible to say that the biggest problem women mention is the low salaries. Besides, the problem of status which is experienced by many women all over the world is another common issue. Another issue that was emphasized by the participants was emotional and physical harassment. This can be commented like a need for change in the way of thinking of society in addition to the developments experienced in education and job definition. The approach that the problem stems not from women but from the devaluation of women (Hon et al, 2005) is to be also considered for Turkey. As the core of the problem is gender-based approach that punishes women and favors men, education women and protecting the status of public relations will never be a long-term solution. Hence, value systems that would give women the value they deserve are to be changed before every other thing in Turkey.

\section{References}

Aldoory, L. and Toth, E. (2002). "Gender Discrepancies in a Gendered Profession: A Developing Theory for Public Relations". Journal of Public Relations Research. 14(2). 103-126.

Al Saqer, S. (2008). "Experience of Female Public Relations Practitioners in Bahrain". Public Relations Review. 34. 77-79.

Becerikli, S. Y. (2008). ...Ve Halkla ilişkiler Şeytanın Avukatlığından Arabuluculuğa; Bir Disiplinin Eleştirel Analizi. Ankara: Karınca Yayınları.

Bıçakçı, A. B. and Hürmeriç, P. (2013). "Milestones in Turkish Public Relations History". Public Relations Review. 39. 91-100.

Broom, G. M. (1982). "A Comparison of Sex Role in Public Relations". Public Relations Review. 8. 17-22. 
Broom, G. M. and Dozier, D. M. (1986). "Advancement for Public Relations Role Models". Public Relations Review. 12. 37-56.

Chavez, C. (2012). "Hispanic Agencies and Profits of Distinction: An Examination of the Advertising Industry as a Field of Cultural Production". Consumption Markets \& Culture. 1-19.

Ciner, O. (2003). Halkla ilişkiler Sektöründe Cinsiyete Dayalı Ayrımcılık (Unpublished Master's Thesis). Ankara: Ankara Üniversitesi Sosyal Bilimler Enstitüsü.

Cline, C. G., Toth, E. L., Turk, J. V., Walters, L. M., Johnson, N., Smith, H. (1986). The Velvet Ghetto: The Impact of the Increasing Percentage of Women in Public Relations and Business Communication. San Francisco: International Association of Business Communications Foundation.

Erdoğan, I. (2008). Teori ve Pratikte Halkla ilişkiler. Ankara: Pozitif Matbaacılık.

Erzikova, E. and Berger, B. K. (2016). "Gender Effect in Russian Public Relations: A Perfect Storm of Obstacles for Women". Women's Studies International Forum. 56. 28-36.

Grunig, L. A., Toth, E. L., Hon, L. C. (2001). Women in Public Relations: How Gender Influences Practice. New York: Guilford.

Hon, L. C., Grunig, L. A., Dozier, D. M. (2005). Women in Public Relations: Problems and Opportunities. J. Grunig (ed.) Excellence in Public Relations and Communication Management. (419-438). Mahwah, NJ: Lawrence Erlbaum Associates.

Khazan, O. (2014, August 8). Why Are There So Many Women in Public Relations?. The Atlantic. http://www.theatlantic.com/business/archive/2014/08/whyare-there-so-many-women-in-pr/375693/.

Lindlof, T. R. and Taylor, B. C. (2017). Qualitative Communication Research Methods. Thousand Oaks, CA: Sage Publications.

McCracken, G. (1951). The Long Interview. Newbury Park, CA: Sage Publications.

Nasr, R. (2015, May 28). Best Jobs for Women in 2015. CNBC. http://www.cnbc. com/2015/05/28/the-best-jobs-for-women-in-2015-.html?slide=11.

Okay, A. and Okay, A. (2007). Halkla ilişkiler Kavram Strateji ve Uygulamaları. i̇stanbul: Der Yayınları.

Öksüz, B. and Görpe, S. (2014). "Türkiye'de Halkla iliş̧kiler Alanında Kadının Yeri: Akademisyenler, Uygulamacılar ve Meslek Örgütü Temsilcilerinin Konuya Yaklaşımları". İstanbul Üniversitesi iletişsim Fakültesi Dergisi. 47. 125-142.

PR Daily. (2011, March 3). In the PR World, Men Still Earn More Than Women. PRDaily. http://www.prdaily.com/Main/Articles/In_the_PR_world_men_still_ earn_more_than_women_7411.aspx.

Salzman, M. (2014, September 23). Why Are There So Many Women in PR?. PR Say. http://prsay.prsa.org/index.php/2014/09/23/why-are-there-so-manywomen-in-pr/.

Tanyıldızı, N. I. (2011). "Türkiye'de Halkla ilişskiler Mesleğinde Kadın". KMU Sosyal ve Ekonomik Araştırmalar Dergisi. 13(20). 75-81. 
Toth, E. L. and Cline, C. G. (1989). Beyond the Velvet Ghetto. San Franscisco: IABC Foundation.

Toth, E. L., Serini, S. A., Wright, D. K., Emig, A. G. (1998). "Trends in Public Relations Roles: 1990-1995". Public Relations Review. 24. 145-163.

TÜHID. (2018a). Tühid Üyeleri. http://www.tuhid.org/tuhid-uyeleri.html.

------ (2018b). Yönetim Kurulu. http://www.tuhid.org/yonetim-kurulu.html. - (2018c). iletişim Fakülteleri. htttp://www.tuhid.org/yerli-iletisim-fakulteleri. html.

TÜiK. (2018, March 6). i̇statistiklerle Kadın 2017. http://www.tuik.gov.tr/PreHaberBultenleri.do?id=27594.

Wright, D. K., Grunig, L. A., Springston, J. K., Toth, E. L. (1991). Under the Glass Ceiling: An Analysis of Gender Issues in American Public Relations. New York: PRSA Foundation.

Yıldırım, D., and Metin, S. (2006). "Halkla ilişkiler ve Cinsiyet". Proceedings of II. Ulusal Halkla Ilişkiler Sempozyumu. 21. Yüzyılda Halkla ilişkilerde Yeni Yönelimler, Sorunlar ve Çözümler. (45-50). Turkey. 